\title{
Different climate response of three tree ring proxies of Pinus sylvestris from the Eastern Carpathians, Romania
}

\author{
Viorica Nagavciuc $^{\mathrm{a}, \mathrm{b}}$, Cătălin-Constantin Roibu ${ }^{\mathrm{a}, *}$, Monica Ionita $^{\mathrm{c}}$, Andrei Mursa ${ }^{\mathrm{a}}$, \\ Mihai-Gabriel $\operatorname{Cotos}^{\mathrm{a}}$, Ionel Popa ${ }^{\mathrm{d}, \mathrm{e}}$ \\ ${ }^{\text {a }}$ Forest Biometrics Laboratory, Faculty of Forestry, "Ștefan cel Mare" University of Suceava, Romania \\ ${ }^{\mathrm{b}}$ National Institute for Research and Development of Isotopic and Molecular Technologies, Department of Mass Spectrometry, Chromatography and Applied Physics, Cluj- \\ Napoca, Romania \\ ${ }^{\mathrm{c}}$ Alfred-Wegener-Institute Helmholtz Centre for Polar and Marine Research, Bremerhaven, Germany \\ ${ }^{\mathrm{d}}$ National Research and Development Institute for Forestry Marin Dracea, Campulung Moldovenesc, Romania \\ ${ }^{\mathrm{e}}$ INCE - Mountain Economy Center CE-MONT Vatra Dornei, Romania
}

\section{A R T I C L E I N F O}

\section{Keywords:}

Tree ring widths

Maximum density chronology

Minimum blue intensity

Climate signal

Dendroclimatology

Daily and monthly climatic data

\begin{abstract}
A B S T R A C T
The aim of this study was to compare the climatic responses of three tree rings proxies: tree ring width (TRW), maximum latewood density (MXD), and blue intensity (BI). For this study, 20 cores of Pinus sylvestris covering the period 1886-2015 were extracted from living non-damaged trees from the Eastern Carpathian Mountains (Romania). Each chronology was compared to monthly and daily climate data. All tree ring proxies had a stronger correlation with the daily climate data compared to monthly data. The highest correlation coefficient was obtained between the MXD chronology and daily maximum temperature over the period beginning with the end of July and ending in the middle of September $(r=0.64)$. The optimal intervals for the temperature signature were 01 Aug - 24 Sept for the MXD chronology, 05 Aug - 25 Aug for the BI chronology, and both 16 Nov of the previous year - 16 March of the current year and $15 \mathrm{Apr}-05$ May for the TRW chronology. The results from our study indicate that MXD can be used as a proxy indicator for summer maximum temperature, while TRW can be used as a proxy indicator for just March maximum temperature. The weak and unstable relationship between $\mathrm{BI}$ and maximum temperature indicates that $\mathrm{BI}$ is not a good proxy indicator for climate reconstructions over the analysed region.
\end{abstract}

\section{Introduction}

Knowledge of present and past climate variability is key to understanding ongoing global climate changes, which means considering climate reconstructions since the instrumental climatic record is too short. In this respect, natural archives can provide quantitative information on past regional to global climate change (IPCC, 2014). Tree rings have great potential for paleoclimatic studies due to their annual resolution, precise dating control, and different proxies, including tree ring width, maximum density, minimum blue intensity, and stable isotopes. Tree rings provide a very strong correlation with climate variables (McCarroll et al., 2002; McCarroll and Loader, 2004; Popa and Kern, 2009; Schweingruber, 1988; Schweingruber et al., 1978; Wilson et al., 2011). The analysis of tree ring width is the traditional method in dendroclimatic research, however, its correlation with climate variables decreases when a climate parameter is not a limiting factor for tree growth. Numerous authors have demonstrated that maximum latewood density (MXD) of coniferous species has a stronger climatic signal compared to the signal from tree ring widths (D'Arrigo et al., 2014; Grudd, 2008; McCarroll et al., 2002; Rydval et al., 2014; Yin et al., 2015). However, this new proxy requires expensive equipment and software, thus limiting its application to a limited number of laboratories (Björklund et al., 2014; Rydval et al., 2014). Therefore, in the pursuit of another more affordable indicator that can provide similar results to MXD chronologies (McCarroll et al., 2002), the blue intensity (BI) was proposed as a proxy indicator for MXD. Later, it was shown that BI has a very strong correlation with MXD chronologies and with climate variables, and thus, has similar efficiency for dendroclimatic studies (Björklund et al., 2014; Campbell et al., 2007; Rydval et al., 2014; Wilson et al., 2011). Unfortunately, there are few studies

\footnotetext{
*Corresponding author at: "Ștefan cel Mare" University of Suceava, Forest Biometrics Laboratory, Faculty of Forestry, 720049 Suceava, Romania. Tel.: + 40 230 216 147; fax: + 400230520080 .

E-mail address: catalinroibu@gmail.com (C.-C. Roibu).
} 
directly comparing tree ring width (TRW), MDX, and BI data (Österreicher et al., 2015). All of these comparison studies have only used monthly climatic data, which do not correspond with the phenological calendar and the cycle of tree growth. As an alternative, Beck et al. (2013) proposed a new method to break the monthly barrier imposed by monthly climatic data by using daily climatic data instead of monthly. This method was since used to study the relationship between climate and TRW (Castagneri et al., 2015; Kaczka et al., 2017; Liang et al., 2013; Pritzkow et al., 2014).

The Eastern Carpathians Mountains offer the ability to create long tree ring chronologies that provide relevant insights about climatic variability and its effect on forest ecosystems (Popa and Sidor, 2010). A good correlation between TRW of Scots pine in the Carpathian Mountains and climate variables has been demonstrated (Bouriaud and Popa, 2007; Popa and Kern, 2009; Popa and Sidor, 2010; Sidor, 2011), but the full dendroclimatological potential of Scots pine in Romania has not been realized because MXD and BI chronologies are missing for this species.

The few existing dendroclimatic reconstructions representative of the Romanian Carpathian Mountains focused only on the TRW. The potential of MXD and BI indicators has not been exploited. Most studies have focused more on the reconstruction of summer mean temperature (Kern et al., 2009; Popa and Bouriaud, 2013; Popa and Kern, 2009; Popa and Sidor, 2010) and precipitation (Kern and Popa, 2016; Levanič et al., 2008), while the relationship with other climatic variables, such as the cloud cover and maximum temperatures, was not taken into account. As such, the aims of this study are: i) to compare MXD, BI, and TRW chronologies developed from the same set of Pinus sylvestris cores taken from the Eastern Carpathian Mountains; ii) to employ monthly and daily data in order to evaluate the potential of each tree ring parameter for dendroclimatic studies; and iii) to determine the optimal time interval for ensuring the highest correlation in future climatic reconstructions.

\section{Material and methods}

\subsection{Study area}

Scots pine trees were sampled from a protected area between 750 and $1200 \mathrm{~m}$ a.s.l., in Zugreni Nature Reserve ( $\left.47^{\circ} 23^{\prime} \mathrm{N}, 25^{\circ} 32^{\prime} \mathrm{E}\right)$, Eastern Carpathians, Romania (Fig. 1). The geological substrate is characterized by crystalline schist with skeletal lithic acid brown soil exposed on a high slope $\left(>35^{\circ}\right)$. The climate in Zugreni Nature Reserve is temperate-continental, with cold winters and mild summers. The monthly mean temperature ranges from $-8.1{ }^{\circ} \mathrm{C}$ (in January) to +14.3 ${ }^{\circ} \mathrm{C}$ (in July). Annual precipitation is $870 \mathrm{~mm}$ with a minimum in February $(46 \mathrm{~mm})$ and a maximum in June $(120 \mathrm{~mm})$.

\subsection{Samples analysis}

20 cores (one radius per tree) were extracted using a $10 \mathrm{~mm}$ diameter Pressler borer from living dominant trees with ages between 80 and 120 years. Sampled trees were located on the middle of the slope with a mean altitude of $1000 \mathrm{~m}$ a.s.l were Pinus sylvestris is widely spread. The limited number of trees selected for coring is justified by the restrictive status of this forest (natural reserve), in accord with the reserve management plan. The increment cores were mounted on wooden supports with their tracheids in the vertical position. Thin laths (thickness of $1 \mathrm{~mm}$ ) were cross-cut perpendicular in the tracheid's direction using a Walesch twin-saw blade DendroCut (https://www. walesch.ch/). In order to extract resins and other soluble components from wood, the thin laths were chemically treated with alcohol in a Soxhlet system for $48 \mathrm{~h}$ according to standard procedure (Schweingruber et al., 1978). Measurement of MXD, BI, and TRW were carried out on the same tree cores.

MXD was measured using radio-densitometric techniques
(Schweingruber et al., 1978). The thin laths were scanned in the Forest Biometrics Laboratory, Stefan cel Mare University of Suceava, Romania, using an Itrax Multiscanner from Cox Analytical Systems (Cox Analytical Systems, 2016). The radiographic images were obtained using the following settings for the $\mathrm{x}$-ray tube: voltage to $30 \mathrm{kV}$, current to $50 \mathrm{~mA}$, exposure time equal to $50 \mathrm{~ms}$, scanning $20 \mu \mathrm{m}$ at a time. A 16 bit, grey level, radiographic (X-ray) digital image was obtained for each sample at 1270 dpi resolution. MXD was measured using the WinDENDRO (2014)density version software. All MXD measurements were carry out under climate-controlled conditions $\left(20^{\circ} \mathrm{C}\right.$ and $50 \%$ relative humidity).

We measured BI following the standard protocol (Campbell et al., 2007; Rydval et al., 2014). The thin laths were scanned using SilverFast software and an Epson 11000XL flatbed scanner with 1200 dpi resolution and saved in 48 bit colour image format. The images were analysed with WinDendro software following the procedure described by (Campbell et al., 2007). Because the BI values are inversely correlated with MXD, all raw BI data was inverted according to Eq (1) (Rydval et al., 2014) to facilitate a direct comparison between BI and MXD:

$\mathrm{X}_{\mathrm{i}(\mathrm{adj})}=2.56-\mathrm{X}_{\mathrm{i}}$

where $X_{i(a d j)}$ represent adjustment values of raw BI, $x_{i}$ is the raw BI value in year $i$, and 2.56 is a constant used to avoid the lower or equal to zero values of $\mathrm{xi}_{(\mathrm{adj})}$, considering all possible values of $\mathrm{xi}\{0 \ldots 255\}$.

TRW was measured using the LINTAB 6 system and TSAPwin software with a precision of $0.001 \mathrm{~mm}$. All chronologies (MXD, BI, and TRW) were individually cross-dated using TSAPwin and statistically verified with COFECHA (Holmes, 1983) using correlation analysis of 50 year intervals with a 25 year overlap (Grissino-Mayer, 2001; Holmes, 1983).

In order to remove potentially non-climatically induced low- and medium-term growth trends, each individual raw data series was transformed into a growth index series. All tree ring series (MXD, BI, and TRW) were detrended by applying a cubic smoothing spline with a $50 \%$ frequency response cut-off at $67 \%$ of each individual series length (Cook and Kairiukstis, 1990). To receive a clear annual climate signal, the remaining autocorrelation was removed by autoregressive modelling, and therefore, we used the residual chronology for the further analyses. Temporal stability was assessed using the expressed population signal (EPS) and inter-series correlation (Rbar). EPS and Rbar were calculated using a 40 year moving window with a 20 year segment overlap (Wigley et al., 1984). The strength of the chronology signal was evaluated using a threshold value of 0.85 for the EPS parameter (Briffa and Jones, 1990).

\subsection{Climate - tree ring growth relationship}

The climate-growth relationship was analysed using five climate variables: mean air temperature (Tmean), maximum air temperature (Tmax), minimum air temperature (Tmin), precipitation (PP), and cloud cover (CLD). Daily data were obtained from the ROCADA gridded data (Dumitrescu and Birsan, 2015) with a resolution of $0.1^{\circ} \times 0.1^{\circ}$ for the period 1961-2013, while the monthly climatic data are based on the CRU TS 4.01 gridded database (Harris et al., 2014) with a resolution of $0.5^{\circ} \times 0.5^{\circ}$ for the period $1901-2015$.

Correlation coefficients between proxy data and climate variables were computed using the R packages $d p l R$ (Bunn, 2008) and treeclim (Zang and Biondi, 2012) for monthly data, and CLIMTREG software (Beck et al., 2013) for the daily data. The daily climatic data brings more precise information about the climatic variations during rings formation, breaking monthly barriers imposed by classical monthly climatic data. CLIMTREG software uses a moving time interval that breaks the monthly limits. The calculation begins on the 1 July of the previous year with a 21 day window and moves one day until 31 


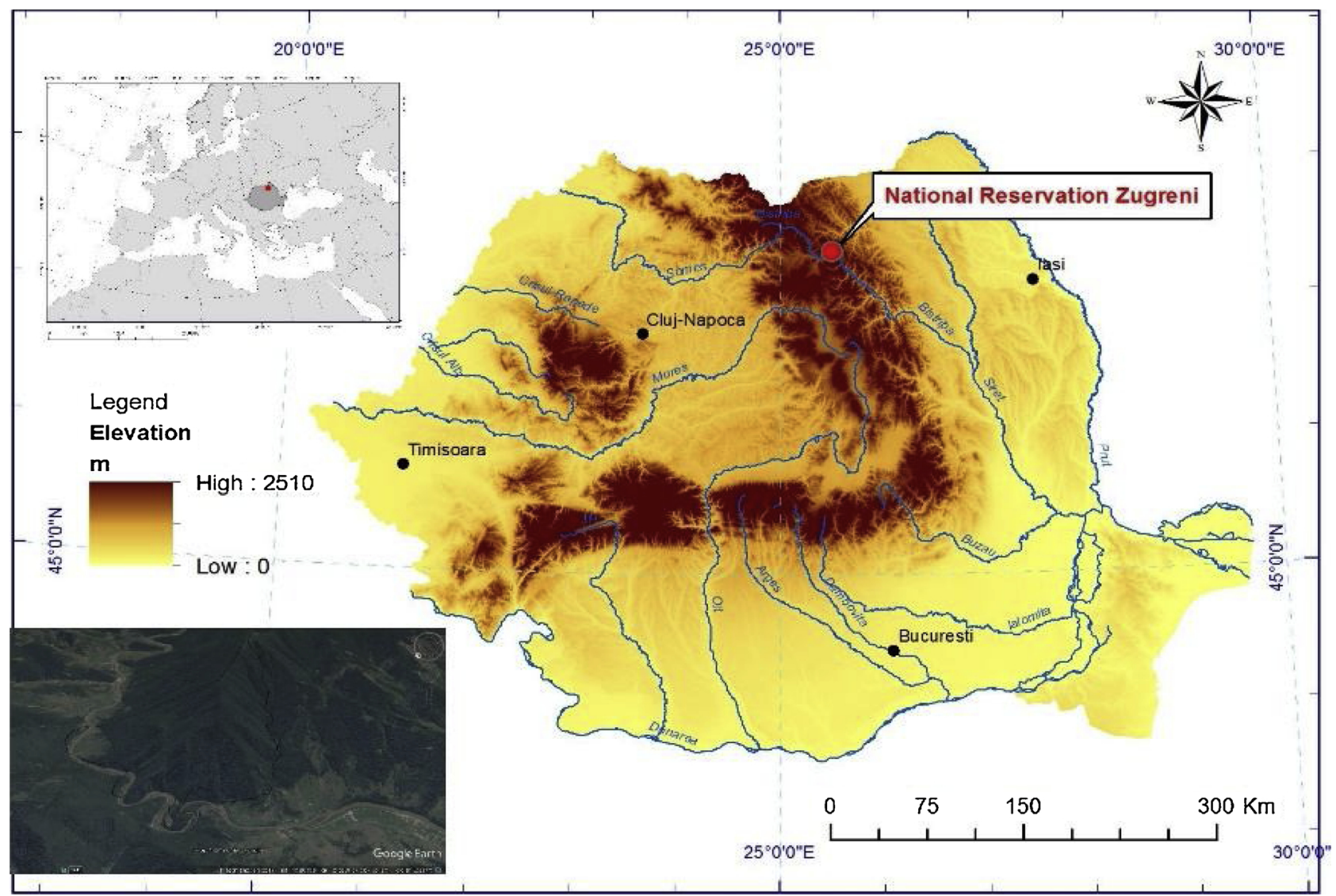

Fig. 1. Location of the study site: Zugreni Nature Reserve, the caption from the top left of figure represent the position of site location at European scale, the caption from the bottom left of figure represent an overview of site location from Google Earths web site.

October of the current year. Afterwards, the time window increases one day and the procedure is repeated. The maximum window length allowed by the software is 121 days (Beck et al., 2013). In this paper, we consider only the correlations that are statistically significant at the 99\% significance level.

\subsection{Stability maps}

To examine the stationarity of the long-term relationship between our proxies and the gridded Tmax dataset we make use of stability maps, a method successfully used in the seasonal forecast of European rivers and Antarctic sea ice (Ionita et al., 2018, 2014, 2008). The concept of predictor stability, wherein the so-called stability maps are a crucial tool, was introduced by (Lohmann et al., 2005). In order to detect stable predictors, the variability of the correlation between the tree ring proxies and the Tmax are investigated within a 31 year moving window within the period 1902-2015. The correlation is considered stable for those regions where the tree rings proxies and Tmax are significantly correlated at the $90 \%$ or $80 \%$ level for more than $80 \%$ of the moving window. A detailed description of the methodology is given in (Ionita, 2017).

\section{Results}

\subsection{Chronology characteristics}

New MXD, BI, and TRW Pinus sylvestris chronologies were developed for the period 1886-2015 and represent maximum overlap of the tree's growth period (Fig. 2). The minimum replication number for which ESP values exceed the threshold of 0.85 (Wigley et al., 1984) was 20 individual series for TRW and 18 for BI after 1935, and only 13 individual series for the MXD after 1915.

The mean inter-series correlation for TRW chronology was 0.273 , for the BI was 0.283 , and the stronger common signal for MXD was 0.297 , which suggested that all of the three parameters have similar signal strength. Inter-chronology correlation between TRW and MXD after standardization was 0.16 , between the TRW and BI was 0.32 , and between MXD and BI was 0.82. This good agreement between interchronology indicates that MXD and BI respond in a similar way to climatic conditions.

The average value of MXD was $1080.8 \mathrm{mg} \mathrm{cm}^{-3}$, with a minimum value $822 \mathrm{mg} \mathrm{cm}^{-3}$ in 1886 and a maximum value of $1220 \mathrm{mg} \mathrm{cm}^{-3}$ in 1960. The amplitude of BI was 167 on the blue intensity scale, with an average colour intensity of 158 . Average TRW was $1.820 \mathrm{~mm}$, with a minimum value of $0.458 \mathrm{~mm}$ in 2016 and a maximum value of $5.977 \mathrm{~mm}$ in 1886. The highest MXD and BI values were observed in 1948,1961 , and 1994, and the highest TRW values were observed in 1951, 1998, 2001, and 2007. The lowest values for MXD, BI and TRW occurred in 1946, 1964, 1976, and 1996.

\subsection{Climate responses to tree ring growth}

To quantify the climatic signal in tree rings it is necessary to identify the optimal interval with the highest correlation coefficient for each climatic parameter. We calculated the monthly data by aggregating the daily grid, and comparing it with the CRU monthly data for the common 1961-2013 period. The correlation coefficients exceeded 0.80 for PP and CLD, and 0.98 for Tmin, Tmax, and Tmean in July and August (Table S1). These results provided confidence that the monthly CRU data, which has a longer time span (1901-2015), had similar performance as the daily ROCADA data and the results obtained with these two data sets were comparable, on monthly time scale. 
a)

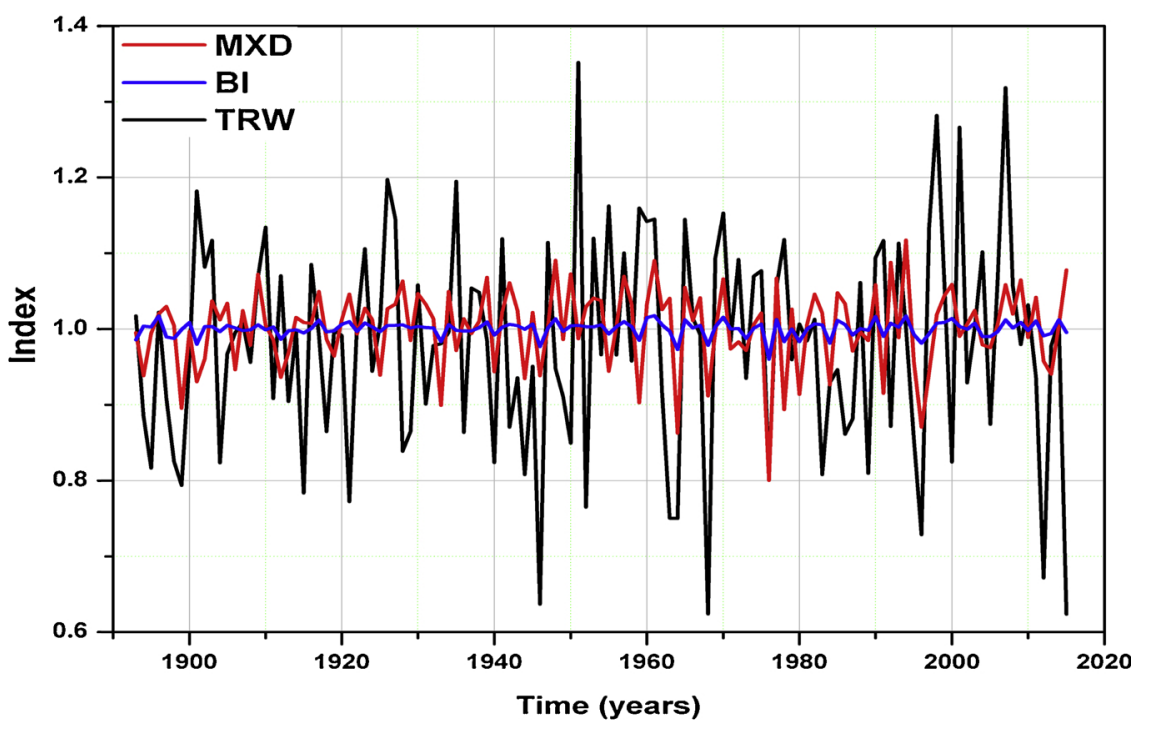

b)

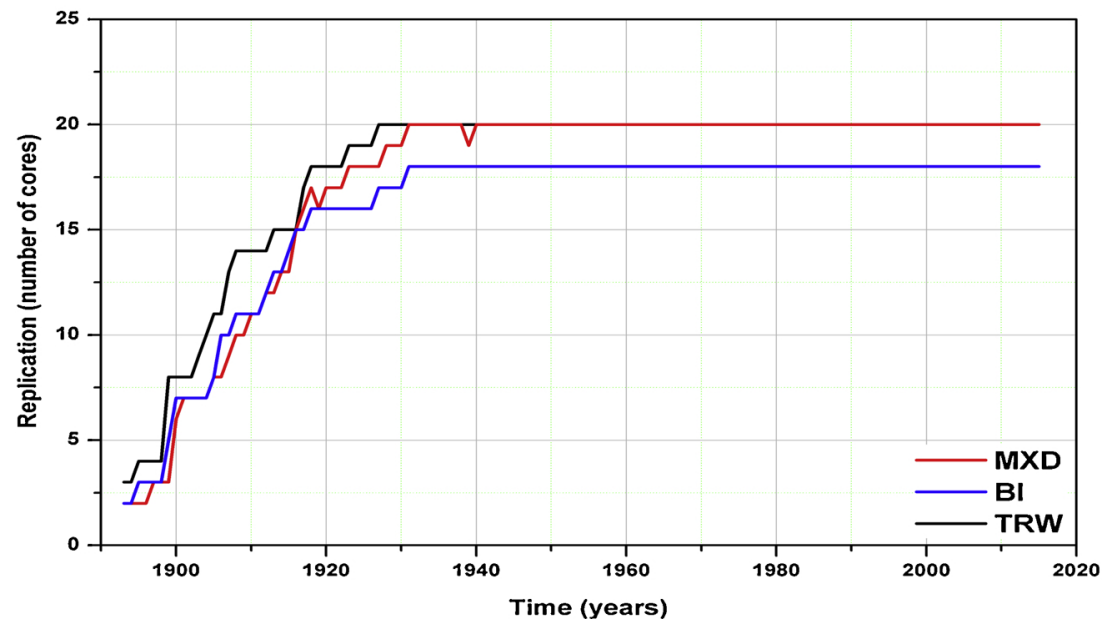

Fig. 2. a) Maximum wood density (MXD - red line), blue intensity (BI - blue line) and tree ring width (TRW - black line) and b) the replication for each tree ring series.

Table 1

The statistically significant correlations of maximum wood density (MXD), blue intensity (BI), and tree-ring width (TRW) with daily climatic data, including mean, maximum, and minimum temperature (Tmean, Tmax, Tmin, respectively), precipitation (PP), and cloud cover (CLD), py means previous year and cy means current year.

\begin{tabular}{|c|c|c|c|c|c|c|}
\hline & \multicolumn{2}{|l|}{ MXD } & \multicolumn{2}{|l|}{ BI } & \multicolumn{2}{|l|}{ TRW } \\
\hline & $r$ & Interval (no days) & $r$ & Interval (no days) & $r$ & Interval (no days) \\
\hline Tmean & 0.59 & $30 \mathrm{Jul}-24$ Sep (57) & 0.53 & 31 Jul - 26 Aug (27) & 0.59 & 17 Nov py - 17 Mar cy (121) \\
\hline Tmax & 0.63 & $30 \mathrm{Jul}-24$ Sep (57) & 0.56 & $30 \mathrm{Jul}-25$ Aug (27) & 0.66 & 18 Nov py - 16 Mar cy (119) \\
\hline Tmin & 0.43 & 01 Aug - 14 Sep (45) & 0.41 & 04 Aug - 26 Aug (23) & 0.55 & 15 Nov py - 15 Mar cy (121) \\
\hline PP & -0.46 & 12 Aug - 02 Oct (52) & -0.45 & $25 \mathrm{Jul}-24$ Aug (31) & -0.42 & 04 Dec py - 17 Jan cy (45) \\
\hline \multirow[t]{2}{*}{ CLD } & -0.62 & 25 Jul - 30 Sept (68) & -0.54 & $25 \mathrm{Jul}-30 \mathrm{Sep}(68)$ & -0.42 & 23 Dec py - 28 Jan (37) \\
\hline & & & & & 0.49 & $18 \mathrm{Mar}-16 \mathrm{Jul}(121)$ \\
\hline
\end{tabular}

The highest correlation coefficients with daily climate data were obtained for the MXD chronology (Table 1), with the highest correlation for daily Tmax $(r=0.63)$, and similar but negative correlation with CLD $(r=-0.62)$ between the end of July and the middle of September. Significant correlations with Tmean $(r=0.59)$ and Tmin $(r=0.43)$ were found for the same period (Figure S1). The correlation coefficient with daily PP $(r=-0.46)$ was lower, but statistically significant (99\% significance level). The correlation coefficients were much lower with monthly climatic data when compared with daily climatic data. The MXD chronology had a significant positive correlation with Tmax $(r=0.49)$ and Tmean $(r=0.44)$ and negative correlation with CLD $(r=-0.43)$ and PP $(r=-0.28)$ in August-September (Table2).

The BI chronology had significant positive correlation coefficients with mean $(r=0.53)$, maximum $(r=0.56)$, and minimum $(r=0.42)$ daily temperature over the period 01 August - 26 August, and negative 
Table 2

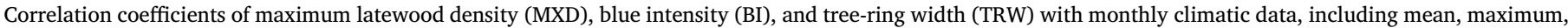
and minimum temperature (Tmean, Tmax, Tmin, respectively), precipitation (PP), and cloud cover (CLD). Significant correlations ( $\mathrm{p}>0.05$ ) are bolded.

\begin{tabular}{|c|c|c|c|c|c|c|c|c|c|c|c|c|c|c|c|}
\hline & \multicolumn{5}{|l|}{ MXD } & \multicolumn{5}{|l|}{ BI } & \multicolumn{5}{|l|}{ TRW } \\
\hline & Tmean & Tmax & Tmin & PP & CLD & Tmean & Tmax & Tmin & PP & CLD & Tmean & Tmax & Tmin & PP & CLD \\
\hline SEP & -0.15 & -0.18 & -0.14 & 0.11 & 0.05 & -0.14 & -0.21 & -0.09 & 0.13 & 0.15 & -0.18 & -0.26 & -0.08 & 0.11 & 0.23 \\
\hline OCT & 0.04 & 0.03 & 0.00 & -0.01 & 0.09 & 0.04 & 0.00 & 0.03 & 0.01 & 0.09 & 0.04 & -0.06 & 0.09 & 0.03 & 0.13 \\
\hline NOV & -0.01 & -0.01 & -0.03 & 0.18 & 0.05 & 0.03 & 0.01 & 0.03 & 0.19 & 0.15 & 0.14 & 0.07 & 0.17 & 0.02 & 0.32 \\
\hline DEC & 0.00 & -0.01 & 0.00 & 0.07 & 0.07 & 0.09 & 0.08 & 0.09 & 0.08 & 0.14 & 0.18 & 0.15 & 0.21 & -0.06 & 0.10 \\
\hline Jan & 0.09 & 0.10 & 0.07 & -0.03 & 0.07 & 0.21 & 0.22 & 0.18 & -0.07 & 0.06 & 0.16 & 0.16 & 0.16 & -0.01 & 0.03 \\
\hline Feb & 0.02 & -0.02 & 0.03 & -0.01 & 0.01 & 0.03 & 0.00 & 0.05 & 0.01 & 0.03 & 0.19 & 0.16 & 0.20 & -0.03 & 0.20 \\
\hline Mar & 0.17 & 0.17 & 0.12 & -0.03 & -0.15 & 0.23 & 0.25 & 0.18 & -0.05 & -0.14 & 0.32 & 0.29 & 0.31 & 0.02 & 0.05 \\
\hline Apr & 0.19 & 0.18 & 0.14 & -0.06 & -0.02 & 0.17 & 0.15 & 0.13 & 0.01 & 0.05 & -0.14 & -0.17 & -0.10 & 0.20 & 0.21 \\
\hline May & 0.18 & 0.20 & 0.12 & -0.08 & -0.23 & 0.13 & 0.16 & 0.09 & -0.03 & -0.18 & -0.16 & -0.21 & -0.08 & 0.12 & 0.21 \\
\hline Jun & 0.10 & 0.06 & 0.11 & -0.01 & -0.08 & 0.04 & 0.00 & 0.05 & 0.08 & 0.03 & 0.01 & -0.08 & 0.11 & 0.14 & 0.23 \\
\hline Jul & 0.21 & 0.21 & 0.15 & -0.29 & -0.11 & 0.10 & 0.08 & 0.07 & -0.17 & 0.02 & -0.02 & -0.11 & 0.07 & 0.18 & 0.19 \\
\hline Aug & 0.41 & 0.46 & 0.27 & -0.17 & -0.34 & 0.36 & 0.40 & 0.23 & -0.15 & -0.29 & -0.07 & -0.17 & 0.03 & 0.10 & 0.13 \\
\hline Sep & 0.31 & 0.35 & 0.16 & -0.26 & -0.36 & 0.17 & 0.22 & 0.04 & -0.26 & -0.29 & -0.08 & -0.13 & -0.04 & 0.05 & 0.01 \\
\hline Oct & 0.05 & 0.08 & -0.01 & 0.04 & -0.16 & 0.07 & 0.10 & 0.00 & -0.01 & -0.17 & 0.05 & 0.04 & 0.05 & -0.02 & -0.13 \\
\hline Nov & 0.02 & 0.03 & -0.01 & -0.08 & -0.14 & 0.01 & 0.03 & -0.02 & -0.11 & -0.14 & -0.07 & -0.11 & -0.05 & -0.07 & -0.03 \\
\hline Dec & 0.10 & 0.10 & 0.08 & -0.13 & -0.18 & 0.06 & 0.05 & 0.05 & -0.05 & -0.08 & 0.05 & 0.02 & 0.04 & 0.04 & 0.03 \\
\hline JJA & 0.31 & 0.34 & 0.20 & -0.24 & -0.27 & 0.21 & 0.23 & 0.14 & -0.12 & -0.13 & -0.03 & -0.16 & 0.08 & 0.22 & 0.27 \\
\hline AS & 0.44 & 0.49 & 0.24 & -0.28 & -0.43 & 0.32 & 0.37 & 0.15 & -0.27 & -0.36 & -0.09 & -0.18 & -0.01 & 0.11 & 0.08 \\
\hline
\end{tabular}

correlations with daily PP ( $r=-0.45)$ over the period 25 July -24 August and daily CLD $(r=-0.54)$ over the period 25 July -30 September (Figure S2). The correlation with monthly data revealed a lower correlation for August and was insignificant for September. In August, BI was positively correlated with Tmax $(r=0.40)$ and Tmean $(r=0.36)$. BI was also negatively correlated with CLD $(r=-0.36)$ in August-September and with PP $(r=-0.26)$ in August.

The TRW chronology was positively correlated with mean, maximum, and minimum daily temperature $(r=0.59, r=0.66$, and $r=0.55$, respectively) over the period 15 November of the previous year (py) - 17 March of the current year (cy). Daily PP $(r=-0.42)$ over the period 24 December py - 26 January cy, daily CLD $(r=-0.44)$ over the period 23 December py - 26 January cy, and daily CLD $(r=0.49)$ over the period 18 March - 16 July were correlated with the TRW chronology (Table 2) (Figure S3). For the TRW chronology, significant positive correlations with monthly climatic data were found only for March temperature (maximum $r=0.29$, mean $r=0.32$, and minimum $r=0.31)$ and November of the previous year CLD $(r=0.32)$. Overall, correlation coefficients with the daily data were much higher than those with the monthly data for all three series and all investigated climatic variables.

\section{Discussion}

\subsection{Correlation with periodic and monthly climate data}

In the mountain region of the Eastern Carpathians, tree ring formation in Scots pine starts at the end of March with activation of cambial activity and the lignification process continues until late September (Semeniuc and Popa, 2014). Environmental characteristics, including climate characteristics, are recorded by tree ring parameters during this period. Because the growth of a tree does not begin with the first day of a calendar month, the correlation coefficients calculated with monthly climatic data represent an approximation of the daily data from that month.

Correlation coefficients obtained with daily climatic data were much higher compared to the correlations obtained with monthly climatic data (Tables 1 and 2). These differences are explained by the greater information content contained in daily data that is not constrained to the limits of a calendar month and better reflects the phenology of tree growth.
MXD shows higher correlation coefficients compared to BI for all analysed climatic variable, confirming previous results that illustrate that the maximum density proxy contains the strongest climate signal (Grudd, 2008; Kaczka et al., 2018; Pritzkow et al., 2014; Tuovinen, 2005). Compared to TRW, MXD shows higher correlation coefficients for PP and CLD, and similar correlation coefficients with temperature, but the correlation periods differed for these two proxies. That the highest correlations coefficients were obtained for MXD suggest that maximum latewood density is less influenced by non-climatic factors (Rydval et al., 2014).

The highest correlation coefficients were obtained between the MXD chronology and daily $\operatorname{Tmax}(r=0.63)$ for the 30 July -24 September period. Also, significantly positive correlations were obtained with daily mean and Tmin ( $r=0.59$ and $r=0.43$, respectively) for the same period, suggesting that temperature represents the most significant growth factor (Schweingruber, 1988; Tuovinen, 2005). Strong correlation with temperature agrees with the theory of McCarroll et al. (2003) that posits the MXD proxy is sensitive to photosynthetic accumulation over the growing season, especially at the end of the growing season explaining the stronger correlations during August and early September. Warm temperatures in August and September facilitate lignification and cell wall thickening, producing the higher lignin content and relatively higher latewood density associated with complete maturation of tracheids, (Campbell et al., 2007; Tuovinen et al., 2009; Yin et al., 2015). Also with the MXD chronology, the significantly negative correlation with CLD $(r=-0.62)$ over the period 30 July - 24 September likely represents an indirect effect of Tmax and hence enhanced photosynthetic rate (Fritts, 1976; Tuovinen, 2005). The significantly negative correlation with daily PP $(r=-0.46)$ over the period 12 August - 02 October might result from high moisture content causing tracheid enlargement (Klusek et al., 2015). Using the monthly climate data, the MXD chronology had significant, but smaller, correlations with temperature and CLD over the June-July-August (JJA) and August-September (AS) periods and with PP during AS.

Statistically significant correlations were also obtained for the BI chronology, which can be regarded as an indirect proxy for MXD since both reflect the lignin content in latewood cell walls (McCarroll et al., 2003, 2002). BI had a similar response as the MXD chronology, confirming previous studies (Björklund et al., 2014, 2013; Campbell et al., 2007; Wilson et al., 2011). The BI chronology had similar correlations as the MXD with correlation coefficients varying between 0.56 for Tmax 


\section{MXD}
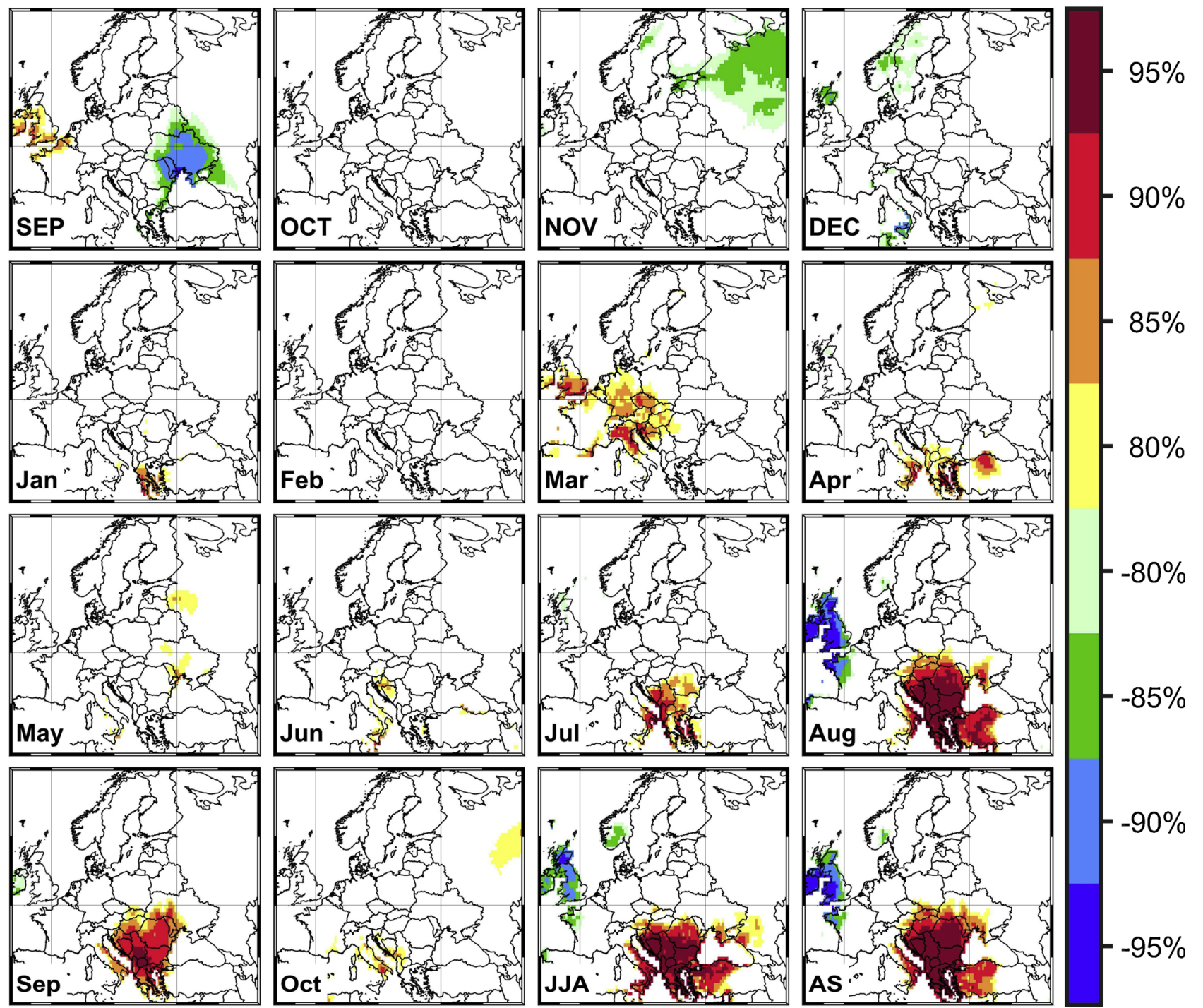

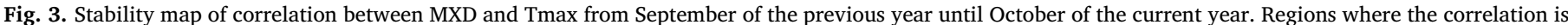

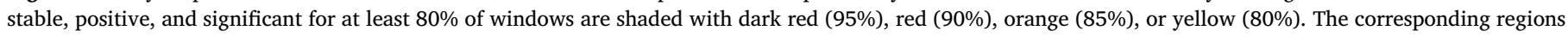

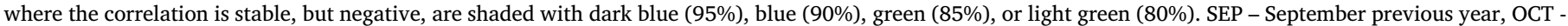

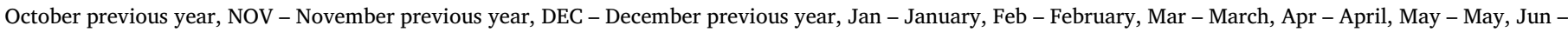
June, Jul - July, Aug - August, Sep - September, Oct - October, JJA - June-July-August, and AS - August-September.

and 0.42 for Tmin, but only for August. The lignification process determined the short duration of correlation for the BI chronology. An analysis of xylem formation in the Scots pine near our study area revealed that the number of xylem cells which were in the thickening phase began to decrease dramatically at the end of August (Semeniuc and Popa, 2014). Nevertheless, for the BI chronology, the correlation period with monthly data increased the correlation period with two months for (August/September), while the correlation coefficient decreased up close to the lower limit of the significance threshold.

In comparison with MXD and BI, the TRW chronology was characterized by weaker and non-significant relationships with climate variables during the growth period, indicating that Scots pine trees from the study site were situated in an area where the climate variables assessed were weakly limiting and radial tree growth was influenced by other non-climatic factors (Grudd, 2008; Schweingruber, 1988; Tuovinen, 2005). Only for CLD for which a positive correlation was recorded over the period 18 March - 16 July, this period corresponds with the start of the growing season and overlaps with the cell enlargement phase (Semeniuc and Popa, 2014). The positive correlation with CLD represents an indirect influence of vapour pressure deficit. High values CLD determine a low-pressure deficit which reduces the transpiration rate and therefore favour the enlargement of cells. TRW was correlated with temperature from the middle of the November py to the middle of March cy. The high correlation during this period resulted from the accumulation of carbohydrates and other organic substances during late autumn after cambial activity had stopped that could subsequently be used in the following spring (Pallardy, 2008). Overall, the large correlation coefficients of the same tree rings proxy for different climate variables is partially explained by the high autocorrelation of climate variables. Moreover, for the TRW chronology, significant correlations with March temperature and CLD in November py were found, but the correlation coefficients were much lower than with daily data.

Variations in density show a stronger climatic signal than TRW because MXD values are more sensitive to climate. Moreover, MXD and BI show larger amplitude than TRW values from one year to the next year, and the yearly variation in the magnitude of the MXD is coherent among all trees from the same site or from sites within a $200 \mathrm{~km}$ radius 


\section{(Conkey, 1979)}

Overall, MXD, BI, and TRW exhibited a stronger correlation with daily data and are useful separately in climatic reconstruction studies. However, combining results from different proxies (TRW with MXD or BI) provides more detailed information about the tree ring-climate relationship and will increase the potential for new paleoclimatic research in Carpathian Mountains where few reconstructions based on TRW exist (Popa and Kern, 2009).

\subsection{Spatial correlation with climate data}

Tree ring proxies are widely used to investigate long-term climate variations (McCarroll and Loader, 2004; Yang et al., 2013). Nevertheless, unstable correlations were found between climate variables and tree ring width (Coppola et al., 2012), density (Briffa et al., 2004), and stable isotopes (Bale et al., 2010; Treydte et al., 2007). In this respect, a stable relationship over time between tree ring proxies and climate variables is crucial for climate reconstructions. To test the stability of the relationship between our proxy data and climate variables, in this study, we computed stability maps between MXD and Tmax with different lags (Fig. 3), as well as stability maps between BI and Tmax (Figure S4) and TRW and Tmax (Figure S5) over the period 1902-2015. The basic idea of the stability map is to identify regions with stable teleconnections (the correlation does not change in time) between our proxy data and Tmax. The stability map between MXD and gridded Tmax indicates that significant and stable correlation coefficients are centred over our study region with extensions over the eastern part of Europe (Fig. 3). For MXD, significant and stable correlations were found over the eastern part of Europe in August and September. The weaker correlation with JJA Tmax confirms results obtained with daily data. The correlation coefficients for BI and TRW with Tmax were much smaller and more local. A much lower temporal stability for the BI-climate relationship compared to the MDX-climate relationship was also reported by Kaczka et al. (2018). For TRW, a stable and significant relationship was found with March Tmax over the eastern part of Europe (Figure S4), while for BI stable and significant correlation were found only with August Tmax. (Figure S5). A general outcome of the stability map analysis is the indication that MXD can be used as a proxy indicator for the summer Tmax due to its stable and statistically significant correlation with August and September Tmax, while TRW can be used as a proxy indicator for March Tmax. The weak and unstable relationship between BI and Tmax indicates that BI is a poor proxy indicator for climate reconstructions over the analysed region.

\section{Conclusions}

Our results suggest that MXD and BI paleoclimate proxies retain a similar paleoclimate signal, while TRW has a different paleoclimate signal. The strongest correlation with all climatic variables was obtained for the MXD chronology, with the highest value for maximum temperature over the time interval extending from the end of July to the middle of September. In addition, a significant correlation was obtained between the BI chronology and August maximum temperature.

The analysis with daily climatic data shows higher larger correlation coefficients when compared with monthly climatic data for all three series and all climatic variables. The optimal interval for the MXD chronology, with the highest largest correlation coefficient, was 30 July - 24 September for maximum temperature, 12 August - 02 October for PP, and 30 July - 24 September for CLD. For the BI chronology, the optimal interval was 30 July - 27 August for maximum temperature, 25 July - 24 August for PP, and 25 July - 30 September for CLD. In the case of the TRW chronology, the optimal interval was 18 November py - 16 March cy for maximum temperature, 24 December py - 26 January py for PP, and 23 December py - 26 January py and 18 March - 16 July for CLD.
The high correlation between MXD and BI and the strong climate signal recorded by both proxies suggest that the BI chronology can be used as a surrogate proxy for MXD, but only for August. The MXD and BI chronologies can also be used in parallel with TRW since they record climatic signals from different periods. Although the correlation coefficients between BI and climate variables was significant, these correlations were not stable over time suggesting that BI cannot be used in climate reconstructions, at least over our analysed region. The results of the present study show that the relationship between climate variables and proxies can be stable or unstable depending of the type of proxy, indicating that caution is needed in paleoclimate reconstruction studies because the stability of the climate signal recorded in paleo proxies is the basis of climate reconstructions.

\section{Acknowledgements}

The research leading to these results received funding from EEA Financial Mechanism 2009 - 2014 under the project contract no CLIMFOR18SEE. PI was partially supported by the project number PNIII-P4-ID-PCE-2016-0253. CCR was partially supported from contract no. 18PFE/16.10.2018 funded by Ministry of Research and Innovation within Program 1 - Development of national research and development system, Subprogram 1.2 - Institutional Performance - RDI excellence funding projects. MI was funded by the Helmholtz Climate Initiative REKLIM.

\section{Appendix A. Supplementary data}

Supplementary material related to this article can be found, in the online version, at doi:https://doi.org/10.1016/j.dendro.2019.02.007.

\section{References}

Bale, R.J., Robertson, I., Leavitt, S.W., Loader, N.J., Harlan, T.P., Gagen, M., Young, G.H.F., Csank, A.Z., Froyd, C.A., McCarroll, D., 2010. Temporal stability in bristlecone pine tree-ring stable oxygen isotope chronologies over the last two centuries. Holocene 20, 3-6. https://doi.org/10.1177/0959683609348867.

Beck, W., Sanders, T.G.M., Pofahl, U., 2013. CLIMTREG: Detecting temporal changes in climate-growth reactions - a computer program using intra-annual daily and yearly moving time intervals of variable width. Dendrochronologia 31, 232-241. https:// doi.org/10.1016/j.dendro.2013.02.003.

Björklund, J.A., Gunnarson, B.E., Seftigen, K., Esper, J., Linderholm, H.W., 2013. Is blue intensity ready to replace maximum latewood density as a strong temperature proxy? A tree-ring case study on Scots pine from northern Sweden. Clim. Past Discuss. 9 5227-5261. https://doi.org/10.5194/cpd-9-5227-2013.

Björklund, J.A., Gunnarson, B.E., Seftigen, K., Esper, J., Linderholm, H.W., 2014. Blue intensity and density from northern Fennoscandian tree rings, exploring the potential to improve summer temperature reconstructions with earlywood information. Clim. Past Discuss. 10, 877-885. https://doi.org/10.5194/cp-10-877-2014.

Bouriaud, O., Popa, I., 2007. Dendroecological reconstruction of forest disturbance history, comparison and parametrization of the methods for Carpathian Mountains. Analele ICAS 50, 135-151.

Briffa, K., Jones, P.B., 1990. Basic chronology statistics and assessment. In: Cook, E.R., Kairiukstis, L. (Eds.), Methods of Dendrochronology: Applications in the Environmental Sciences. Kluwer Academic Publishers, Dordrecht, pp. pp. 137-152.

Briffa, K.R., Osborn, T.J., Schweingrubber, F.-H., 2004. Large-scale temperature inferences from tree rings: a review. Glob. Planet. Change 40, 11-26.

Bunn, A.G., 2008. A dendrochronology program library in R (dplR). Dendrochronologia 26, 115-124. https://doi.org/10.1016/j.dendro.2008.01.002.

Campbell, R., Mccarroll, D., Loader, N.J., Grudd, H., Robertson, I., Jalkanen, R., Campbell, R., Mccarroll, D., Loader, N.J., Robertson, I., Jalkanen, R., 2007. Blue intensity in Pinus sylvestris tree-rings : developing a new palaeoclimate proxy. Holocene 17, 821-828. https://doi.org/10.1177/0959683607080523.

Castagneri, D., Petit, G., Carrer, M., 2015. Divergent climate response on hydraulic-related xylem anatomical traits of Picea abies along a 900-m altitudinal gradient. Tree Physiol. 35, 1378-1387. https://doi.org/10.1093/treephys/tpv085.

Conkey, L.E., 1979. Response of Tree-Ring Density to Climate in Maine, U. S. A. Tree-ring bulletin 39, 29-38.

Cook, E.R., Kairiukstis, L.A., 1990. Methods of Dendrochronology. Applications in the Enviromnental Science.

Coppola, A., Leonelli, G., Salvatore, M.C., Pelfini, M., Baroni, C., 2012. Weakening climatic signal since mid-20th century in European larch tree-ring chronologies at different altitudes from the Adamello-Presanella Massif (Italian Alps). Quat. Res. 77, 344-354. https://doi.org/10.1016/j.yqres.2012.01.004.

Cox Analytical Systems, 2016. Itrax M u l t i s c a n n e r and XRF Element Analysis in One 
Instrument for Wood Analysis. [WWW Document]. URL (Accessed 2.6.15). wWw. coxsys.se.

D’Arrigo, R., Davi, N., Jacoby, G., Wilson, R., Wiles, G., 2014. Dendroclimatic Studies: Tree Growth and Climate Change in Northern Forests. John Wiley \& Sons pp 88.

Dumitrescu, A., Birsan, M., 2015. ROCADA: a gridded daily climatic dataset over Romania (1961-2013) for nine meteorological variables. Nat. Hazards 78, 1045-1063. https://doi.org/10.1007/s11069-015-1757-z.

Fritts, H.C., 1976. Tree Rings and Climate. Academic Press, London.

Grissino-Mayer, H.D., 2001. Evaluating crossdating accurasy: a manual and tutorial for the computer program Cofecha. Tree. Res. 57, 205-221.

Grudd, H., 2008. Torneträsk tree-ring width and density AD 500-2004: a test of climatic sensitivity and a new 1500-year reconstruction of north Fennoscandian summers. Clim. Dyn. 31, 843-857. https://doi.org/10.1007/s00382-007-0358-2.

Harris, I., Jones, P.D., Osborn, T.J., Lister, D.H., 2014. Updated high-resolution grids of monthly climatic observations - the CRU TS3.10 Dataset. Int. J. Climatol. 34, 623-642. https://doi.org/10.1002/joc.3711.

Holmes, R.L., 1983. Computer-assisted quality control in tree-ring dating and measurement. Tree Ring Bulletin 43, 69-75.

Ionita, M., 2017. Mid Range Forecasting of the German Waterways Streamflow Based on Hydrologic, Atmospheric and Oceanic Data. Bremerhaven, 711. .

Ionita, M., Lohmann, G., Rimbu, N., 2008. Prediction of spring Elbe discharge based on stable teleconnections with winter global temperature and precipitation. J. Clim. 21, 6215-6226. https://doi.org/10.1175/2008JCLI2248.1.

Ionita, M., Dima, M., Lohmann, G., Scholz, P., Rimbu, N., 2014. Predicting the June 2013 european flooding based on precipitation, soil moisture, and sea level pressure. J. Hydrometeorol. 16, 598-614. https://doi.org/10.1175/JHM-D-14-0156.1.

Ionita, M., Scholz, P., Grosfeld, K., Treffeisen, R., 2018. Moisture transport and Antarctic sea ice: austral spring 2016 event. Earth Syst. Dyn. Discuss. 9, 939-954. https://doi. org/10.5194/esd-2017-114.

IPCC, 2014. IPPC Climate Change 2014 Synthesis Report, Climate Change 2014: Synthesis Report. Contribution of Working Groups I, II and III to the Fifth Assessment Report of the Intergovernmental Panel on Climate Change. Geneva, Switzerland. https://doi. org/10.1017/CBO9781107415324.

Kaczka, R., Janecka, K., Hulist, A., Czajka, B., 2017. Linking the growth/climate response of daily resolution with annual ring formation of Norway spruce in the Tatra Mountains. Trace 15, 13-22.

Kaczka, R.J., Spyt, B., Janecka, K., Beil, I., Büntgen, U., Scharnweber, T., Nievergelt, D., Wilmking, M., 2018. Different maximum latewood density and blue intensity measurements techniques reveal similar results. Dendrochronologia 49, 94-101. https:// doi.org/10.1016/j.dendro.2018.03.005.

Kern, Z., Popa, I., 2016. Dendrochronological and radiocarbon analyses of subfossil oaks from the foothills. Geochronometria 43, 113-120. https://doi.org/10.1515/geochr2015-0038.

Kern, Z., Popa, I., Varga, Z., Széles, É., 2009. Degraded temperature sensitivity of a stone pine chronology explained by dendrochemical evidences. Dendrochronologia 27, 121-128. https://doi.org/10.1016/j.dendro.2009.06.005.

Klusek, M., Melvin, T.M., Grabner, M., 2015. Multi-century long density chronology of living and sub-fossil trees from Lake Schwarzensee, Austria. Dendrochronologia 33, 42-53. https://doi.org/10.1016/j.dendro.2014.11.004.

Levanič, T., Gričar, J., Gagen, M., Jalkanen, R., Loader, N.J., McCarroll, D., Oven, P., Robertson, I., 2008. The climate sensitivity of Norway spruce [Picea abies (L.) Karst.] in the southeastern European Alps. Trees 23, 169. https://doi.org/10.1007/s00468008-0265-0.

Liang, W., Heinrich, I., Simard, S., Helle, G., Liñán, I.D., Heinken, T., 2013. Climate signals derived from cell anatomy of scots pine in NE Germany. Tree Physiol. 33, 833-844. https://doi.org/10.1093/treephys/tpt059.

Lohmann, G., Rimbu, N., Dima, M., 2005. Where can the Arctic oscillation be reconstructed? Towards a reconstruction of climate modes based on stable teleconnections. Clim. Past Discuss. 1, 17-56. https://doi.org/10.5194/cpd-1-17-2005.

McCarroll, D., Loader, N.J., 2004. Stable isotopes in tree rings. Quat. Sci. Rev. 23, 771-801. https://doi.org/10.1016/j.quascirev.2003.06.017.

McCarroll, D., Pettigrew, E., Luckman, A., Guibal, F., Edouard, J.L., 2002. Blue reflectance provides a surrogate for latewood density of high-latitude pine tree rings. Arct. Antarct. Alp. Res. 4, 450-453.
McCarroll, D., Jalkanen, R., Hicks, S., Tuovien, M., Gagen, M., Pawellek, F., Eckstein, D., Schmitt, U., Autio, J., Heikkinen, O., 2003. Multiproxy dendroclimatology: a pilot study in northern Finland. Holocene 13, 829-838.

Österreicher, A., Weber, G., Leuenberger, M., Nicolussi, K., 2015. Exploring blue intensity - comparison of blue intensity and MXD data from Alpine spruce trees. Trace 10, 56-61. https://doi.org/10.2312/GFZ.b103-15069.

Pallardy, S.G., 2008. Physiology of Woody Plants, third edition. Elsevier Academic Press.

Popa, I., Bouriaud, O., 2013. Reconstruction of summer temperatures in Eastern Carpathian Mountains (Rodna Mts, Romania) back to AD 1460 from tree-rings. International Journal of Climatology. https://doi.org/10.1002/joc.3730. n/a-n/a.

Popa, I., Kern, Z., 2009. Long-term summer temperature reconstruction inferred from tree ring records from the Eastern Carpathians. Clim. Dyn. 32, 1107-1117.

Popa, I., Sidor, C., 2010. Rețeua romaneasca de dendrocronologie RODENDRONET 1. Conifere. Editura Silvica.

Pritzkow, C., Heinrich, I., Grudd, H., Helle, G., 2014. Relationship between wood anatomy, tree-ring widths and wood density of Pinus sylvestris L. And climate at high latitudes in northern Sweden. Dendrochronologia 32, 295-302. https://doi.org/10. 1016/j.dendro.2014.07.003.

Rydval, M., Larsson, L.-A., McGlynn, L., Gunnarson, B.E., Loader, N.J., Young, G.H.F., Wilson, R., 2014. Blue intensity for dendroclimatology: should we have the blues? Experiments from Scotland. Dendrochronologia 32, 191-204.

Schweingruber, F.H., 1988. Tree Rings Basics and Applications of Dendrochronology. Kluwer Academic Publishershttps://doi.org/10.1007/978-94-009-1273-1.

Schweingruber, F.H., Fritts, H.C., Braker, U.O., Drew, L.G., Schar, E., 1978. The X-Ray technique as applied to dendroclimatology. Tree-Ring Bulletin 38, 61-91.

Semeniuc, A., Popa, I., 2014. Xylem formation in coniferous species in Călimani Mts. During the 2013 growth season. Analele Universităţii din Oradea. Fascicula: Protecția Mediului 23, 543-548.

Sidor, C., 2011. Relatia dintre climat si cresterea radiala a arborilor din zona montana superioara. Teze de doctorat. Bucuresti. .

Treydte, K., Frank, D., Esper, J., Andreu, L., Bednarz, Z., Berninger, F., Boettger, T., D'Alessandro, C.M., Etien, N., Filot, M., Grabner, M., Guillemin, M.T., Gutierrez, E., Haupt, M., Helle, G., Hilasvuori, E., Jungner, H., Kalela-Brundin, M., Krapiec, M., Leuenberger, M., Loader, N.J., Masson-Delmotte, V., Pazdur, A., Pawelczyk, S., Pierre, M., Planells, O., Pukiene, R., Reynolds-Henne, C.E., Rinne, K.T., Saracino, A., Saurer, M., Sonninen, E., Stievenard, M., Switsur, V.R., Szczepanek, M., SzychowskaKrapiec, E., Todaro, L., Waterhouse, J.S., Weigl, M., Schleser, G.H., 2007. Signal strength and climate calibration of a European tree-ring isotope network. Geophys. Res. Lett. 34. https://doi.org/10.1029/2007GL031106.

Tuovinen, M., 2005. Response of tree-ring width and density of Pinus sylvestris to climate beyond the continuous northern forest line in Finland. Dendrochronologia 22, 83-91. https://doi.org/10.1016/j.dendro.2005.02.001.

Tuovinen, M., McCarroll, D., Grudd, H.åk., Jalkanen, R., Los, S., 2009. Spatial and temporal stability of the climatic signal in northern Fennoscandian pine tree-ring width and maximum density. Boreas 38, 1-12. https://doi.org/10.1111/j.1502-3885.2008. 00046.x.

Wigley, T.M.L., Briffa, K.R., Jones, P.D., 1984. On the average value of correlated time series, with applications in dendroclimatology and hydrometeorology. J. Clim. Appl. Meteorol. 23, 201-213. https://doi.org/10.1175/1520-0450(1984) $023<0201$ :OTAVOC $>2.0$.CO; 2 .

Wilson, R., Loader, N.J., Rydval, M., Patton, H., Frith, A., Mills, C.M., Crone, A., Edwards, C., Larsson, L., Gunnarson, B.E., 2011. Reconstructing Holocene climate from tree rings: the potential for a long chronology from the Scottish Highlands. Holocene 22, 3-11. https://doi.org/10.1177/0959683611405237.

Yang, F., Wang, N., Shi, F., Ljungqvist, F.C., Wang, S., Fan, Z., Lu, J., 2013. Multi-proxy temperature reconstruction from the West Qinling Mountains, China, for the past 500 years. PLoS One 8. https://doi.org/10.1371/journal.pone.0057638.

Yin, H., Liu, H., Linderholm, H.W., Sun, Y., 2015. Tree ring density-based warm-season temperature reconstruction since A.D. 1610 in the eastern tibetan plateau. Palaeogeogr. Palaeoclimatol. Palaeoecol. 426, 112-120. https://doi.org/10.1016/j. palaeo.2015.03.003.

Zang, C., Biondi, F., 2012. Dendroclimatic calibration in R: The bootRes package for response and correlation function analysis. Dendrochronologia. https://doi.org/10. 1016/j.dendro.2012.08.001. 


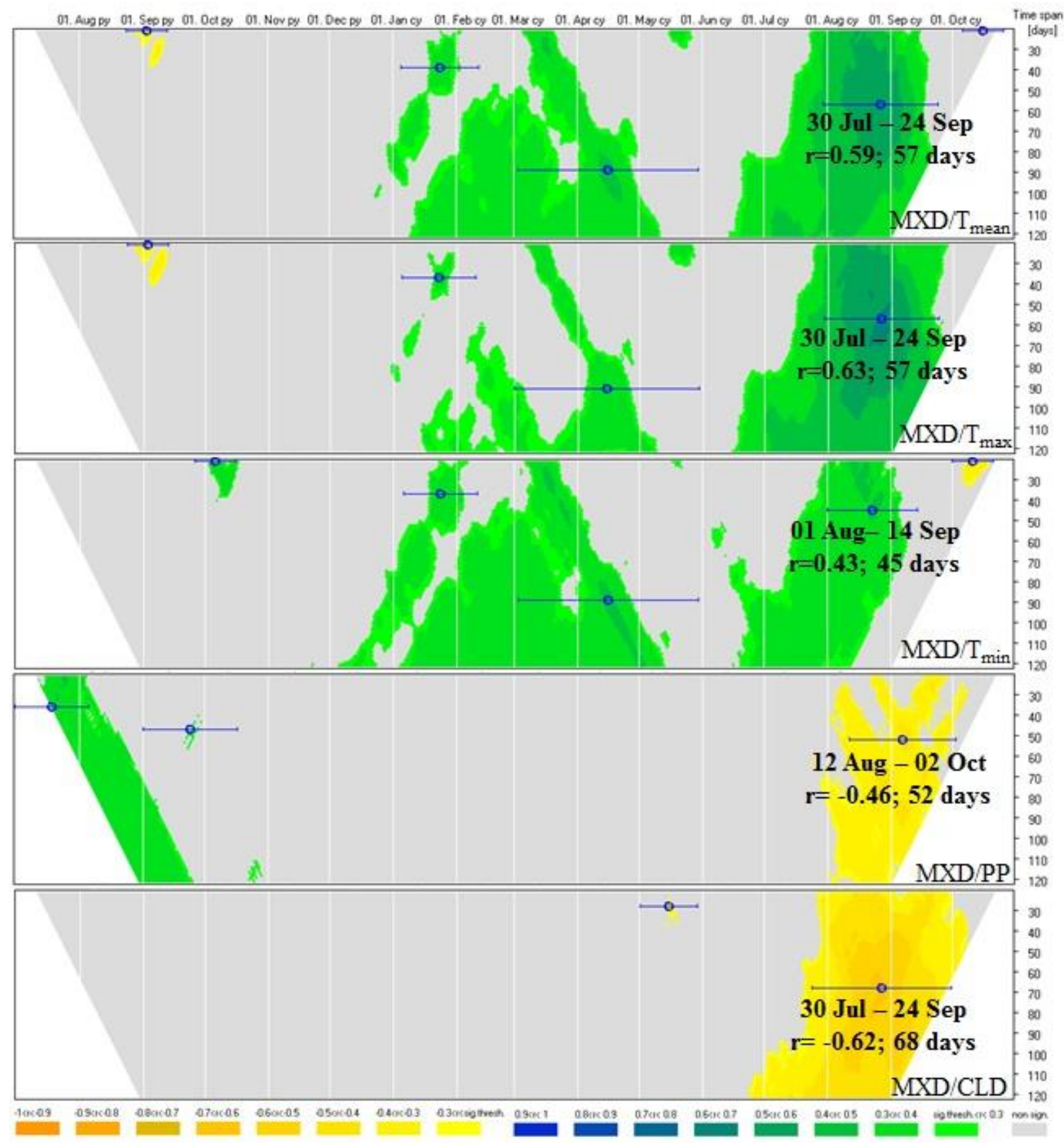

Figure S1. Results of the correlation analysis between maximum density (MXD) and daily climatic parameters (minimum temperature (Tmin), mean temperature (Tmean), maximum temperature (Tmax), precipitation (PP) and cloud cover (CLD)) over the period 1961-2013. The time intervals which have the highest correlation coefficient are indicated by circles, and the beginning and the end of the corresponding time intervals are indicated by horizontal bars. The color coding for the significance level of correlations is reported below the graphs. White vertical lines highlight the first day of each month. 


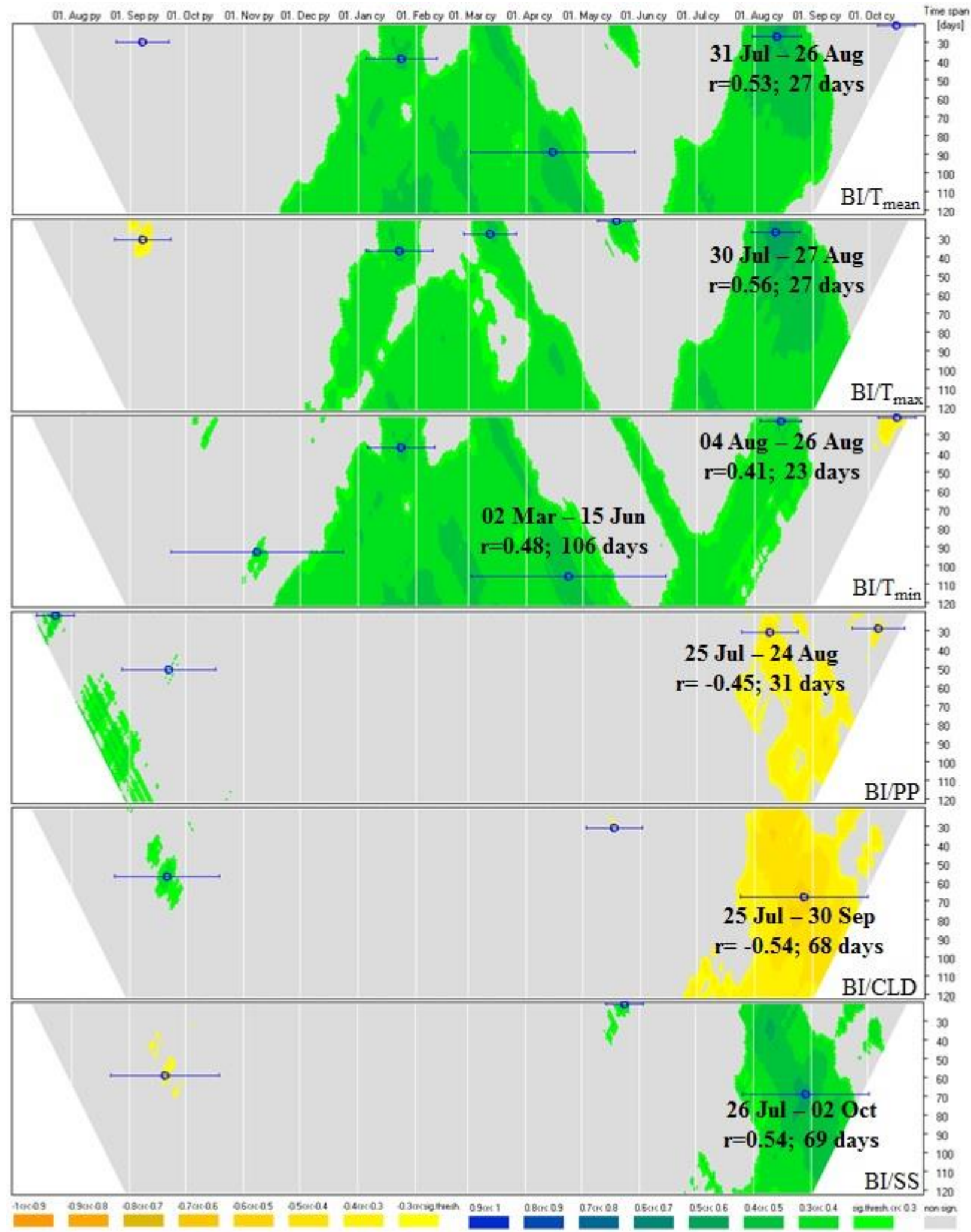

Figure S2. Results of the correlation analysis between blue intensity (BI) and daily climatic parameters (minimum temperature (Tmin), mean temperature (Tmean), maximum temperature (Tmax), precipitation (PP) and cloud cover (CLD)) over the period 1961-2013. The time intervals which have the highest correlation coefficient are indicated by circles, and the beginning and the end of the corresponding time intervals are indicated by horizontal bars. The color coding for the significance level of correlations is reported below the graphs. White vertical lines highlight the first day of each month. 


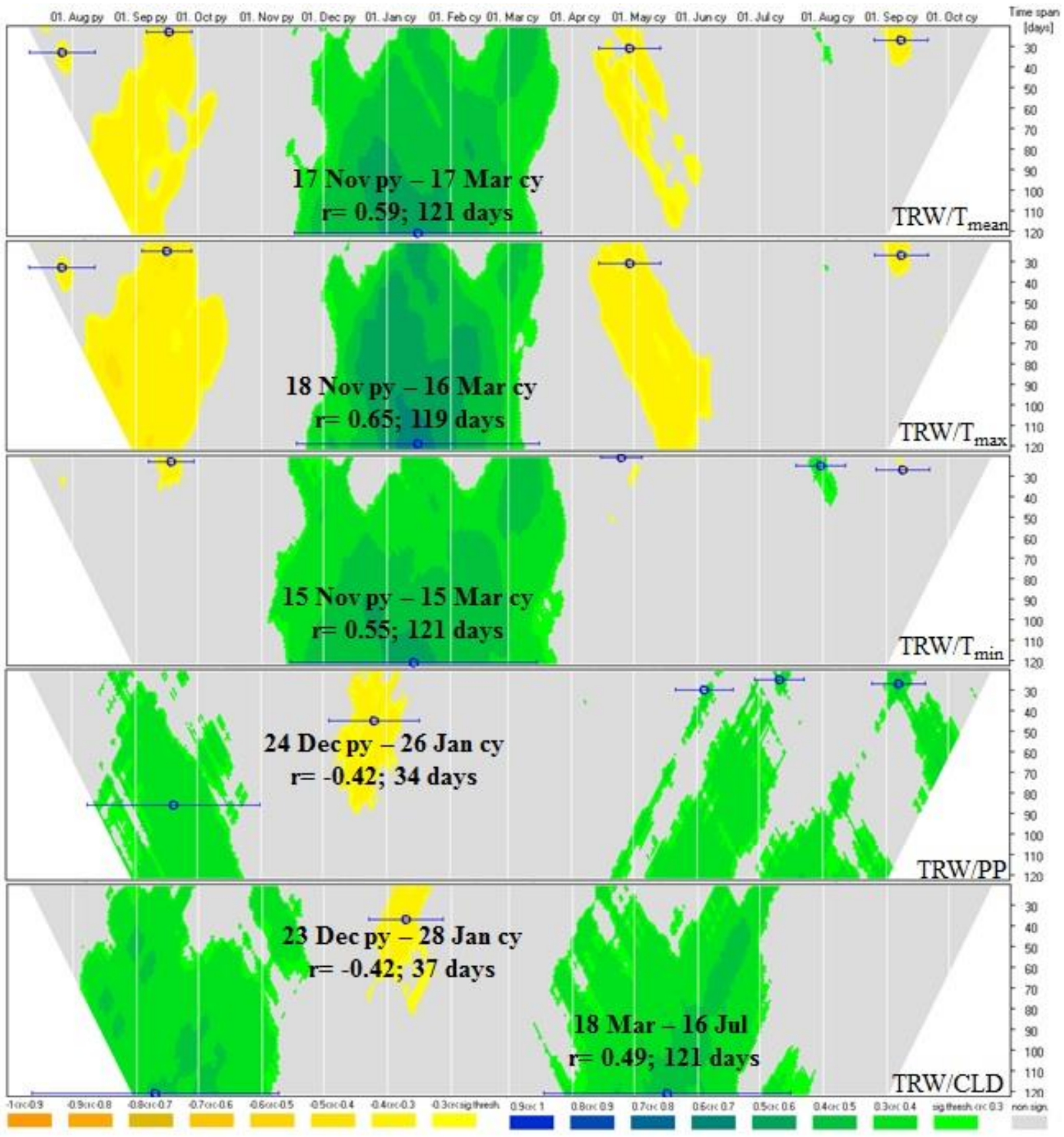

Figure S3. Results of the correlation analysis between tree ring width and (TRW) daily climatic parameters (minimum temperature (Tmin), mean temperature (Tmean), maximum temperature (Tmax), precipitation (PP) and cloud cover (CLD)) over the period 1961-2013. The time intervals which have the highest correlation coefficient are indicated by circles, and the beginning and the end of the corresponding time intervals are indicated by horizontal bars. The color coding for the significance level of correlations is reported below the graphs. White vertical lines highlight the first day of each month. 


\section{TRW}
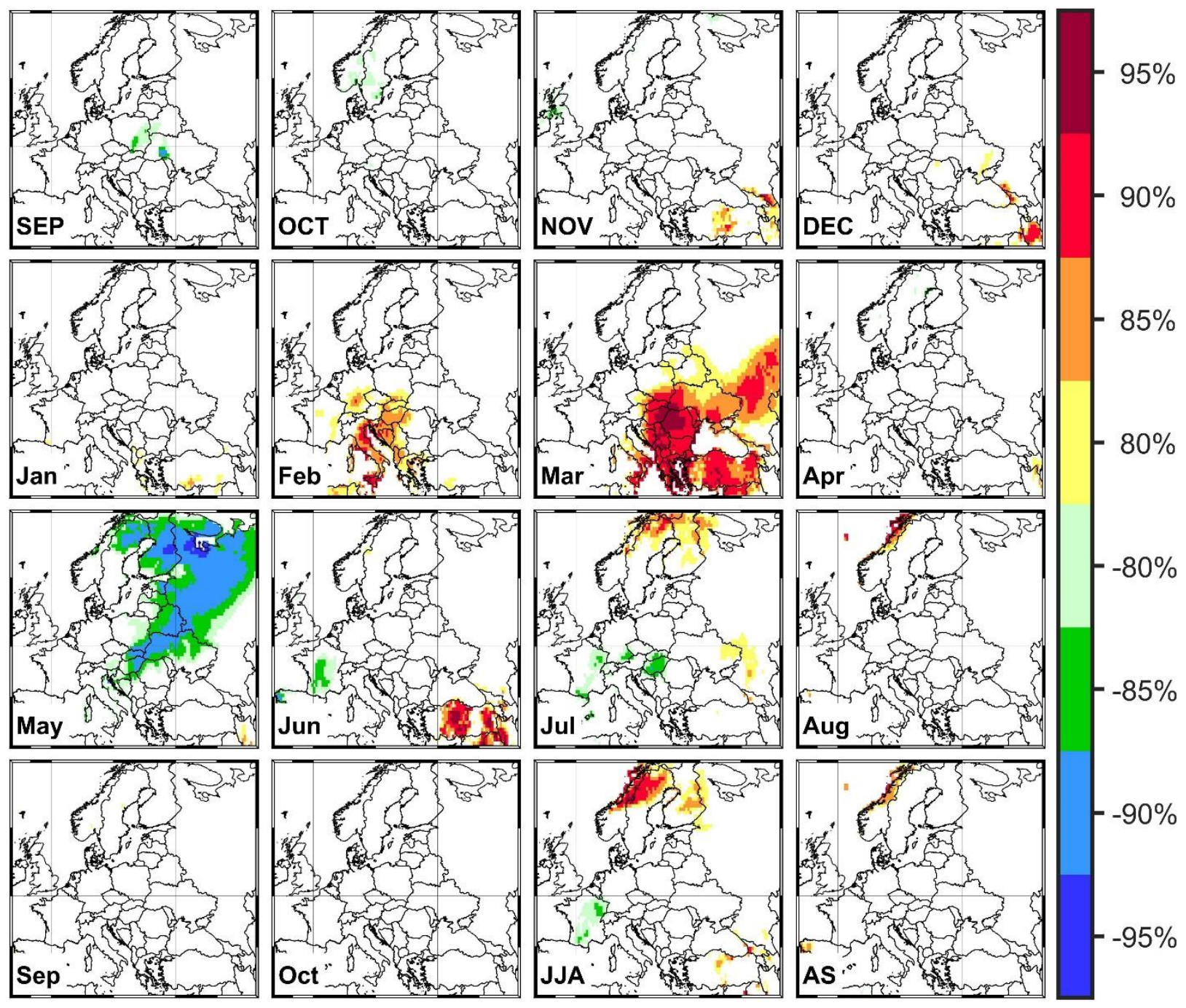

Figure S4. Stability map of the correlation between TRW and Tmax from September previous year until Ocotber same year. Regions where the correlation is stable, positive and significant for at least $80 \%$ windows are shaded with dark red $(95 \%)$, red $(90 \%)$, orange $(85 \%)$ and yellow $(80 \%)$. The corresponding regions where the correlation is stable, but negative, are shaded with dark blue (95\%), blue (90\%), green $(85 \%)$ and light green $(80 \%)$. SEP - September previous year, OCT - October previous year, NOV November previous year, DEC - December previous year, Jan - January, Feb - February, Mar - March, Apr - April, May - May, Jun - June, Jul - July, Aug - August, Sep - September, Oct - October, JJA June/July/August and AS - August/September. 


\section{BI}
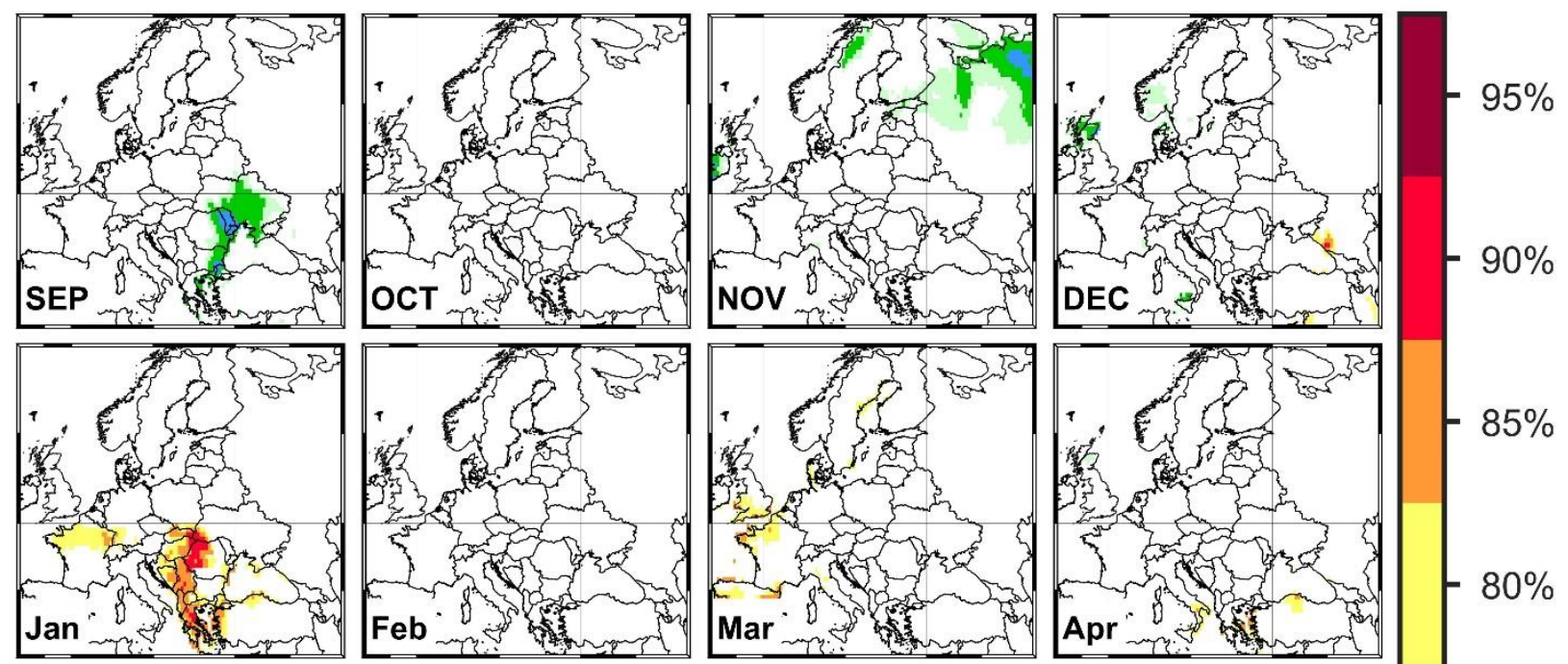

$-85 \%$
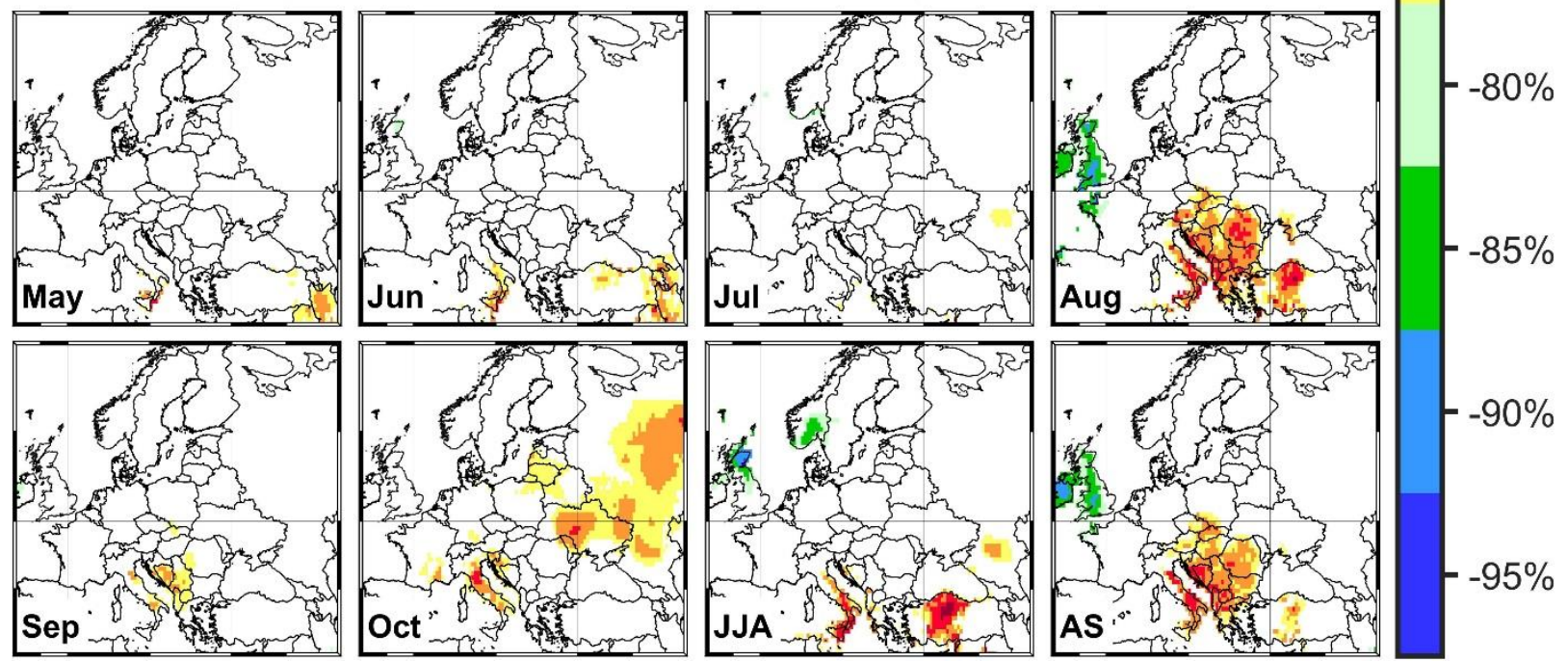

Figure S5. Stability map of the correlation between BI and Tmax from September previous year until Ocotber same year. Regions where the correlation is stable, positive and significant for at least $80 \%$ windows are shaded with dark red (95\%), red (90\%), orange (85\%) and yellow (80\%). The corresponding regions where the correlation is stable, but negative, are shaded with dark blue (95\%), blue (90\%), green $(85 \%)$ and light green $(80 \%)$. SEP - September previous year, OCT - October previous year, NOV November previous year, DEC - December previous year, Jan - January, Feb - February, Mar - March, Apr - April, May - May, Jun - June, Jul - July, Aug - August, Sep - September, Oct - October, JJA June/July/August and AS - August/September. 
Table S1. Correlation between CRU and ROCADA monthly data

\begin{tabular}{|l|r|r|r|r|r|}
\hline & Cloud & PP & Tmin & Tmed & Tmax \\
\hline Jan & 0.71 & 0.88 & 0.98 & 0.98 & 0.98 \\
\hline Feb & 0.80 & 0.80 & 0.99 & 0.99 & 0.98 \\
\hline Mar & 0.80 & 0.80 & 0.98 & 0.99 & 0.98 \\
\hline Apr & 0.83 & 0.89 & 0.98 & 0.99 & 0.98 \\
\hline May & 0.88 & 0.88 & 0.98 & 1.00 & 0.98 \\
\hline Jun & 0.68 & 0.85 & 0.97 & 0.99 & 0.99 \\
\hline Jul & 0.85 & 0.80 & 0.98 & 0.99 & 0.99 \\
\hline Aug & 0.92 & 0.82 & 0.98 & 0.99 & 0.99 \\
\hline Sep & 0.76 & 0.90 & 0.96 & 0.99 & 1.00 \\
\hline Oct & 0.80 & 0.91 & 0.98 & 0.98 & 0.99 \\
\hline Nov & 0.75 & 0.82 & 0.99 & 0.99 & 0.99 \\
\hline Dec & 0.61 & 0.86 & 0.97 & 0.98 & 0.97 \\
\hline
\end{tabular}

